\title{
Rola światla słonecznego we wnętrzu współczesnego kościoła
}

The role of sunlight in the interior of a contemporary church

\section{Streszczenie}

Przedmiotem analiz, zawartych w artykule jest rola światta dziennego, jego wpływ na ksztattowanie i odbiór architektury oraz ta słra swiątyni. Od najdawniejszych lat $w$ szczególności dla obiektów sakralnych religii chrześcijańskiej element świat strzeni, podkreśla i uwidacznia architekture, wpływa na jej estetyczna forme jednocześnie staje sie wyznacznikiem emoci

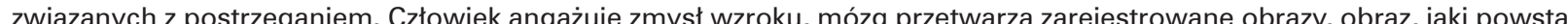
w mózgu jest efektem odbitego światta, które obite od widzianego obrazu wpada do oka. Każdy z nas widzi inaczej. Jednocześnie istnieja wspólne powtarzalne zbiory wrażeń, które decyduja o walorach estetycznych. To, jak i jakie światto wpłływa na ksztaltowanie plastyki wnętrza obiektów sakralnych, staje się wyznacznikiem postrzegania przestrzeni sacrum.

\section{Abstract}

The article analyses the role of daylight, its influence on shaping and reception of architecture and interior of a temple. Since the earlest days, especially for sacred bulldings of the Christian religion, the element of sunilght has been a necessary determinant for the emerging churches. Sunlight determines the reception of space, emphasizes and reveals the architecture, influences its aesthetic form, and, at the same time, becomes a determinant of emotions related to perception. People engage their sight, the brain processes the recorded innages, the image, that is generated in the brain, is the result of reflected light, which, reflected from the viewed image, hits the eye. Everyone sees differently. At the same time, there are some common repeatable collfiom the vividness of the interior of sacred buildings and how it happens becomes a de. Whition

\section{Wstep, analiza problemu}

Znaczenie i wpływ światta słonecznego na odbiór architektury wykorzystywano już w kulturze antycznej. W kulturach solarnych, kult słońca był dalece związany z obrzędowością wyznaniowa. W kulturze chrześcijańskiej, jak i w wielu kulturach, krzyż był pierwszym znakiem solarnym, natomiast światto słoneczne nabrało szczególnego znaczenia w początkach $V$ w., kiedy to zapożyczone $z$ antyku orientowanie świątyn stało się niemal do końca XIX w. obowiązującą regułą. Stanowito ono pierwszą czynosc wy połozenie cienia przy wschodzie i zachodzie wyznaczało os wschód zachód, jednocześnie było pierwszym wprowadzonym promieniem swiatta do wytyczanej świątyni. W histori budownictwa sakralnego element swiatla słonecznego stanowil istotne, wręcz nieodzowne narzędzie, potrzebne podczas wytyczania obiektu i wpisywania go w obszar. Orientowanie kościołów stanowiło ważną czynność symboliczną. Chrześcijanie tak na wschodzie jak i na zachodzie modlili się zwrócen ku wschodowi. Tak to wyraża Orygenes: „przystoi modlić sie ku wschodowi, na znak zwrotu duszy ku prawdziwemu świat

\section{Introduction, problem analysis}

The importance and influence of sunlight on the reception of architecture was already used in ancient culture. In solar cultures, worship of the sun was closely related to religious rituals. In Christian culture, just like in many others, the cross was the first solar ing tance at the beginning of the $5^{\text {th }}$ century, when orien-

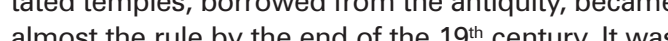
the first activity during the of the 19 in century. It was of shade on the east and on the west determined the east-west axis; at the same time, it was the firs ray of light entering the planned temple. In the history of sacred architecture, the element of sunlight was an essential tool, indispensable even, needed to plan the building and set it within the area. The activity. Christians, both in the enst and in the west prayed facing east. This is how Origen in the west, "...the east as the direction we should turn to ( since the soul ought to keep its eyes steadily turned towards the rising of the true Light." [1, p. 22]. Now- fu" [1, s. 22]. Współcześnie, orientowanie kościołów przestało głych. Obecnie twórcy niezbyt często rozumieja znaczenia symboliki, kanonu lokalizacji, dlatego też nie nawiazuja do niej i jej wartości znaczeniowych. Symbolika ta niosła kiedys ze soba wèdrowkę światła $w$ przestrzeni wnętrza kościoła [4 s. 105]. Odejście od orientowania nie pozbawiło kościołów swiatła słonecznego, jednakże różne ich usytuowania i sposoby doświetlenia spowodowały nieoczekiwane efekty wizualne, czy rzeczywiście wpływaja one pozytywnie na walory estetyczne wnetrz kościotów?

Wśród twórców wspótczent? za sie poszukiwanie najodpowiednieszej ich fomy, natomiast we wnetrach kościów mistycinego iduchowego ich wyrazu, wielokro hie uzywaja w od hiesieniu do wow

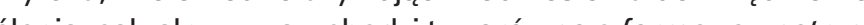
slenia- sakr lis wyaz, chodzi tu zarowno o formę zewnętrzna (brylę), jak i jej wyposazenie i aranzację Whętrza, z dowartosciowaniem rangiswiatta oraz koloru. Dopiero calosc, kompozycja tych wszystkich elementowicznnikow wspoorksztattuje sakralny klimat [4, s. 38].

\section{2. Światło we wnętrzu, jego rola}

jako kreatora projektów architektonicznych, a również i wnętrz przestrzeni sakralnych wspołistnieje z nim i dzięki niemu jest widzialna. Znaczenie swiatła wykorzystywane jest takze w wielu obiektach tworzonych wspólcześnie. Architekci wykorzystują naturalhe swiatlo, jego projekcję dającą nieskończenie wiele intensywności dla treści wnętrza. Często odgrywa ono samodzielną, pierwszoplanową rolę. Przykładem jednego z wielu architektów może być Tadao Ando, który w swej twórczości w projektach dokładnie przewiduje elementy oświetlenia i kształty cieni a każde wprowadzenie promieni do wnetrza jest kontrolowane poprzez ich sttumienie, i odbicie, przykładem tego jest Kościót Światta w Osace [5, s. 324] (il. 1). Natomiast Mario Bo harmonii, również poprzez stosowanie podstawo o niezwykłej proporij i symetii. Jego umiejetnó́c operowani śmiatem propos

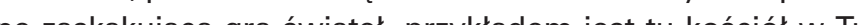
rynie (il. 2).

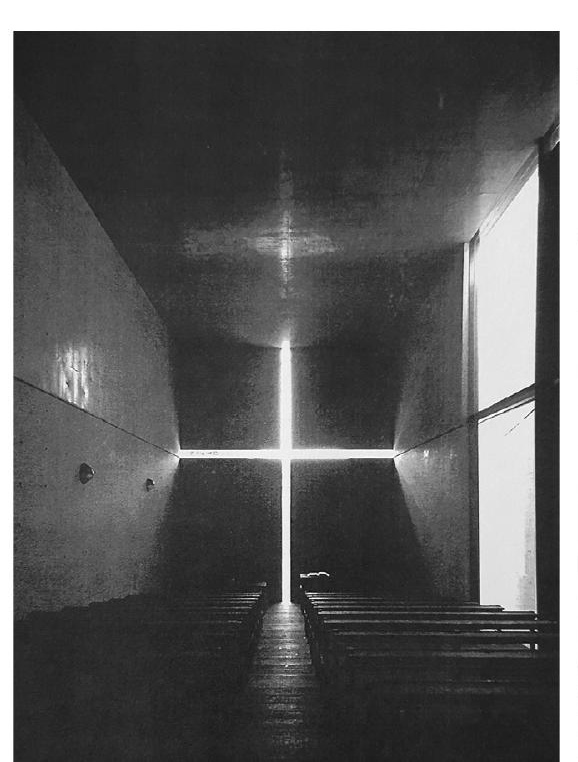

adays, the orientation of churches stopped playing such a leading symbolic role as it did in the past. Currently, creators rarely understand the meaning of symbols, the canon of location, and therefore symbolism used to be redited with the values. This of light in the interior space of the church [4, s. 105]. The departure from the orientation of churches has not deprived them of sunlight, but their differen locations and ways of lighting caused unexpected visual effects. Do they really influence the aesthetic values of the interiors of churches in a positive way? Among the creators of contemporary sacred buildings, we can notice the search for the most es - their mystical and spiritual expression, often describing the interiors as sacred, both for the external form (structure), as well as the design of the interior, raising the status of light and colour. It is only the final result, the composition of all these elements and factors, that contributes to the sacred atmosphere [4, p. 38].

\section{Light in the interior and its role}

. very popular. Architecture disappears without light, it coexists with it and is visible thanks to it. The meaning of light is also used in many buildings constructed today. Architects use natural light and its projection which brings an infinitely great amount of intensity to the content of the inOrerior. It often plays an independent, leading role. signs precisely predict the lighting elements and shapes of shades, and each insertion of rays into the interior is controlled by their suppression and reflection, like in the Church of the Light in Osaka $[5$, s. 324], ( II.1). On the other hand, designs of Mario Botta use basic building materials, creating architecture of extraordinary harmony, also by applying the basic rules of proportion and symmetry. isterior of sacred buildings filled with a surprising play of lights, like in the church in Turin (il.2) Light can be called a "material of illumination", is changeable, even impossible to be determined permanently. Each time, it can be seen differently, despite the same space observed with the same A play of lights causes changes in the ob- 
Światło można nazwać "materiałem iluminacji” jest zmienne, wręcz nie dające się okrestic na stale. Kazdorazowo można je widzieć inaczej, pomimo tej samej obserwowanej przestrzen z tym samym wykończeniem i elementami wyposażenia. Gra świateł powoduje zmienne nastroje odczuć obserwatora, jednakże wprowadzona odpowiednio do dobrze przemyślanej przestrzeni kształtuje ją i wzbogaca. Wspomniany materiał iluminacii” stał sie narzedziem, równiez w reku polskich architektów. Spośród wspótczesnych realizacii obiektów sakranych Andrzej Mroczek i Konrod Kucza-Kuczynski w ksiazce nych Andrzej Nroczek i Kon Ka Kucza-Kuczynski w ksiązce 1990 pzy 1900 prykioly wolsce wydan poswięcono achitekture kosciolów krakowskich na

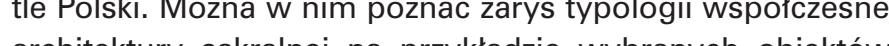

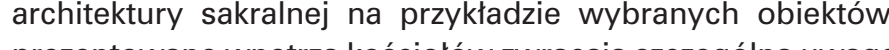
prezentowane wnętrza kościolow zwracają szczególną uwage na rolę światla jaką $w$ nim odgrywa.

Swiatio, zarowno naturalne jak i sztuczne, jest jednym z najważniejszych czynników definiujących wnętrze. Poprzez odbite od przedmiotow światto nasze oko dostrzega kolory wnętrza, ich emocjonalny odbiór decyduje o postrzeganiu i odczuwaniu. W naszym umysle powstaje odbiór rzeczywistego obrazu który decyduje o zaklasyfikowaniu, w odczuciu subiektywnym, widzianej przestrzeni jako piękno, a w przypadku obiektów sakralnych można mówić o oddziaływaniu na sferę duchową i przypisanie widzianemu obrazowi wzniosłości.

W posoborowej architekturze sakralnej, ostatnich czterdziestu lat, można wyodrębnić różne sposoby wprowadzania światta do wnętrz kościołów, zarówno w przestrzeni nawy jak i prezbiterium, najczęściej spotykane sposoby to:

- całościowe przeszklenie ściany prezbiterium

- całościowe przeszklenia jednej ze ścian nawy

- górne światto wprowadzone poprzez podłużne świetliki dachowe, podkreślające układ osiowy wnętrza

- cześciowe przeszklenie ściany prezbiterium w pionie lub poziomie

- górne światło wprowadzone poprzez lunety kierunkowe

z ukierunkowaniem na prezbiterium lub bezpośrednio na z ukier

- boczne lub centralne światło szczelinowe w ścianie prezbiterium

- światło szczelinowe w przestrzeni nawy, pionowe w układzie parawanowych ścian

- poziome pasmowe światło w przestrzeni naw

- okna przenikające się z połaciami dachów

- wielokierunkowe układy przeszk

- mieszane układy doświetlenia

Światło, w przestrzeni wnętrz obiektów sakralnych odbierane jest ze zmiennym natężeniem doznań emocjonalnych. $\mathrm{Na}$ różnicę odbiorów i postrzegania wpływ mają czynniki kształtującej architekturę, począwszy od orientowania obiektu, lokalizacji obiektu, sposobie zastosowanego doświetlenia strefy oftarza oraz nawy, kończąc na plastyce wnętrza i zastosowanych kolorach we wnętrzu, typie materiałów, sposobie i kolorach wypełniających szklenie okien. Okna w kościele to otwory w murze, pionowe lub pasmowe. Okna te umieszczone są najczęściej w płaskich ścianach i ich załamaniach, server's moods, however, properly introduced into the well-thought-out space that shapes and enriches it. This "material of illumination" has become a tool, also in the hands of Polish architects. In their book called "Nowe koscioły w Polsce" [3], Anchosen and discussed examples of contem, have sacred architecture built in Poland by 1990. This atbum issue is devoted to the architecture of Krakó churches against the background of Poland. It shows the outline of the typology of contemporary sacred architecture on the example of selected buildings, the presented interior of churches ar Light, both natyral and artificial, is onays in it. important factors defining the one of the most light reflected from objects, our eye perceives the colours of the interior, their emotional reception determines our perception and impressions. Our mind creates the reception of a real image, that conditions the subjective classification of the viewed space as beautiful, and in the case of sacred buildings, we can talk about influencing the to the viewed image.

In the post-conciliar sacred architecture of the last forty years, we can identify various ways of introducing light to the interior of churches, both in the nave area, as well as in the chancel; the most common ways are:

full glazing of the chancel wa

full glazing of a nave wal

upper light introduced through longitudinal skyaxial arrangement of the

vertical or horizontal partial glazing of the chancel wall

- upper light introduced through directional teleto the altar

side or central slit light in the chancel wall slit light in the nave area, vertical in the system of screen wall

- windows penetrating the nave area - multidirectional glazing systems - mixed lighting systems Light in the space of sacred buildings' interior is interpreted with varying intensity of emotional experiences. Differences in perceptions are influenced by factors shaping the architecture, from orientation of the building, its location, the type of
lighting in the altar and nave areas to the visuals of the interior and the colours used in the visuals type of materials, in the way and colours filling the window glazing. Windows in the church are holes in the wall, vertical or strip-like. These windows are usually placed in flat walls and their folds, multiplied, duplicated as slots in unseen places, or as glazing filling the openwork walls or skeletal spaces of walls and roofs.

3. Analysis of selected examples of lighting the church interiors

People engage their sight, the brain processes the zwielokrotnione, powielone jako szczeliny w niewidocznych ełniające ażurowe ściany lub szkieletowe przestrzenie ścian i dachów.

3. Analiza wybranych przypadków doświetlenia wnętrz kościołów

Człowiek angażuje zmysł wzroku, mózg przetwarza zarejestrowane obrazy, obraz, jaki powstaje w mózgu, jest efektem odbitego swiatr, ktore odbite od widzin do oka. Każdy z nas wir

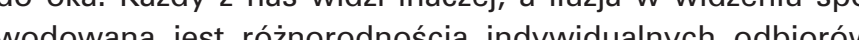

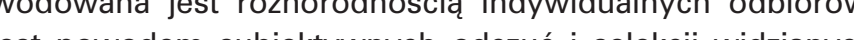
ws

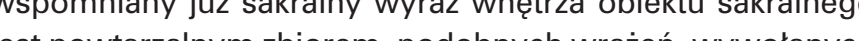
prez wpadajace do wnem, podobych wrazen, wy wolanych

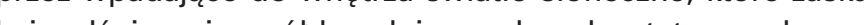
kuje, olshiewai wsótdecyduje o walorach estetycznych przestrzeni świątyni. Jednocześnie wszystkie te zbiory doznań sa efektem pracy twórczej nad architekturą i plastyką wnętrza. Architekci, tworząc nowe swiątynie poszukiwali rozwiązan które najbardziej odpowiadałyby założeniom soborowym. $W$ analizie uwagę skupiono na nowo powstalych obiektach sakralnych w obszarze Pomorza Zachodniego, ściśle archidiecezji szczecińsko-kamienskiej, spośrod nowo powstałych obiektow przeanalizowanych zostala ich większosć, wśród nich wyodrębnione zostały grupy obiektów posiadając wspomniane sposoby wprowadzanie światła do wnętrza. Wśród powstałych obiektów pojawiły się pojedyncze rozwiązania, np. oparte na rzucie wycinka koła np. kościół św. Krzyża w Szczecinie, gdzie światło wprowadzone zostało poprzez całościowe przeszklenie ściany prezbiterium, oraz ściany przeciwległej. Kościół zaprojektowano na rzucie wycinka koła gdzie dwa jego promienie połączono od strony południowego zachodu półkolista ściana tworzaca zamknieccie prezbiterium. Ściane zamykajaca stanowia regularnie ustawione, na tuku żelbetowe słupy, pomiedzy którymi przestrzeń wypetnion jest wielobarwnym witrażem, tworzacym zarówno the ottarza, jak i doświetlenie wnetrza Ściana północno-wschodnia to

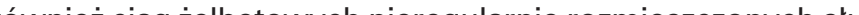
pów o zmiennej wysokości. Przestrzeń pomiedzy nimi wype litadank $z$ pojedynczego rożnokolorowe

II. 3. Kościót pw. Św. Krzyża w Szczecinie, Zbigniew Abrahamowicz, 1972,2
cin, Zbigniew Abrahamowicz, 1972. Source: author's own material

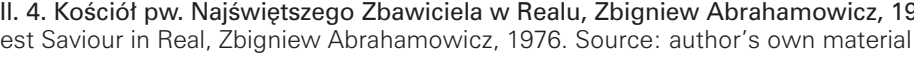
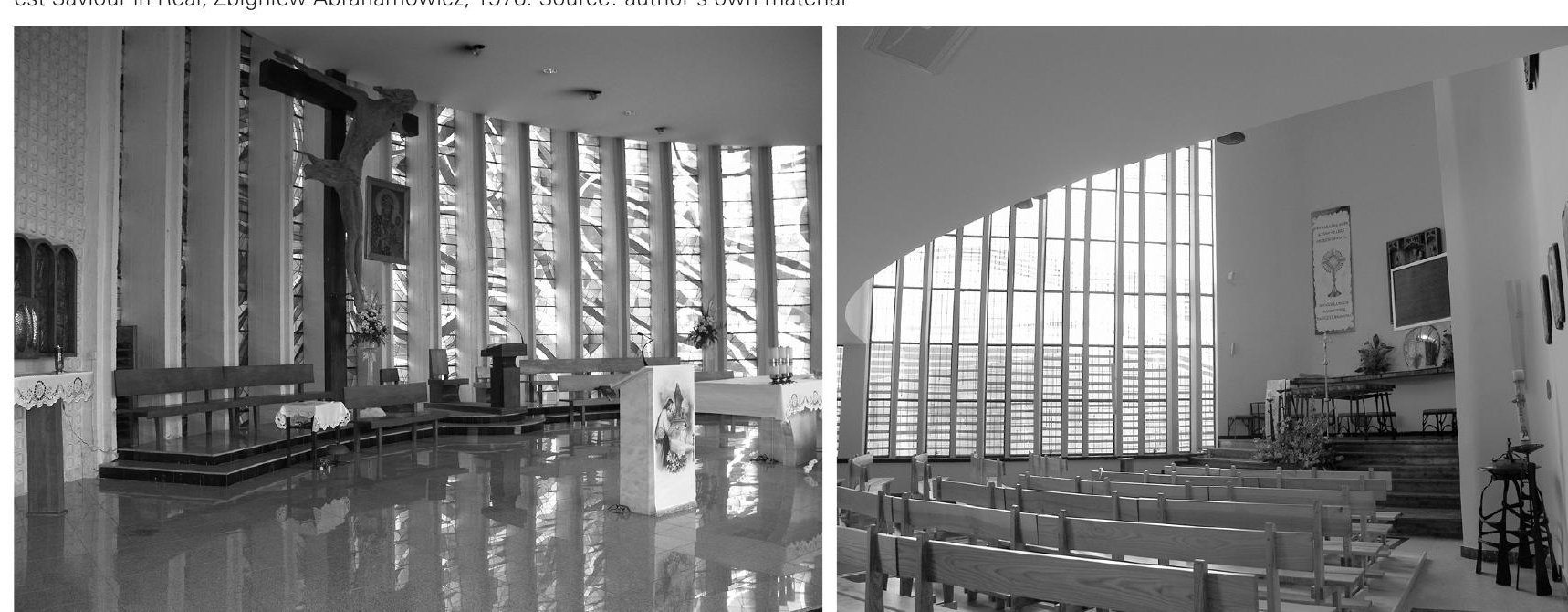

in the brain is the result of reflected light, which, reflected from the viewed image, hits the eye. Ev is the reason for subjective feelings and selection of the viewed images. At the same time, there are sions which determine the aesthetic value. What type of light influences shaping the vividness of becomes a determinant of the perception of the sacred space. We can say that for people beauty $f$ the mentioned perceptible sacred expression the interior of a sacred building is a repeatable dazzles and co determines the aeshetic qualities of the temple space. At the same time, all these collections of experiences are the result of creative work on architecture and interior design. new solutions that would best fit the conciliar principes The analysis focuses on the newly established

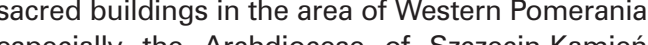
The groups of buildiocese of Szczecin-Kamien, of introducing light into the interior mentioned ways from the newly created buildings.

The said buildings have some individual solutions, e.g. based on the projection of a circular segment e.g. the Saint Cross Church in Szczecin, where light was introduced through full glazing of the Wancel wall, and the opposite wall. The church was designed on the projection of a circular sector wert with a radii were merged from the southof the with a semi-circular wall forming the closure we on an arch, the space between them is filled with multi-coloured stained glass, creating both the the interior. The north-east wall is also a series of iregularly arranged reinforced concrete columns of varying heights. The space between them is

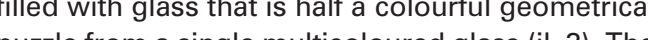
Way of fom a single multicoloured glass (il. 3). The space, deprives it of a clear orientation. Although is caused by diversty, and the illusion in vision the interior of sacred buildings and how it happens sunlight coming in the sunlight that surprise

When creating new temples, architects sought out background of the altar, and additional lighting for 
sób wprowadzenia światła słonecznego do wnętrza rozbija iż szklana ściana prezbiterium skupia wzrok wiernego, to intensywność i kolory witraża przy bardzo jasnym słonecznym dniu oślepiają wiernego. Przejaskrawione wnętrze nie tworzy nastroju skupienia, jedynie cienie $z$ bocznych przestrzeniach kościoła wyciszają wrażenie natłoku.

Kolejnym przykładem jest kościół Najświętszego Zbawiciela w Rewalu, tu światto wprowadzone zostało przez catościowe przeszloni jednej ze ścian nawy. Architekt zastosowat plo przeszlenia jecie ze scian nawy. Architekt zastosowat plan terium, gdzie ściane prezbiteria zamknt w miejscu spotkania sie promien kla. Dwa ta w ten spoś́b cześć wycink kota stanowi strefe olatala w ten sposób częsc wycinka kola stanowi strefę oftarza. Ramiona rozchodza się od centrum prezbiterium, powstala

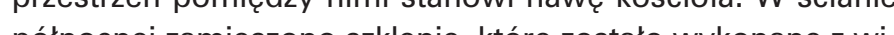
pólnocnej zamieszono szklenie, które zostalo wykonane z witrazy, w strefie wejsciowej doświetlenie wprowadzono wąskimi czterema pionowymi oknami. Pizestrzen whętrza wy pełniona jest żródłem niknących promieni słońca, wczesnego wschodu i pojawiająacych się poźnym zachodem (il. 4).

Przykładem opartym na nieregularnym układzie rzutu, jest kościół Miłosierdzia Bożego w Szczecinie, orientowany, gdzie światio wprowadzone zostalo przez gorny podłuzny swietliki dachowy, podkreślający układ osiowy wnętrza oraz boczne pasma okien w płaszczyznach ukośnych ścian. Swiątynia zaprojektowana została na planie nieregularnego wieloboku, zakończonego niewyodrębnionym prezbiterium, które podkreślone jest wiązką światta dziennego. Bryła głównej części obiektu składa sie z ukośnie zestawionych ze soba ścian o zmiennej wysokości. Pomiędzy ścianami powstałe przestrzenie, wypełniono witrażami i kolorowym szkłem, doświetlaja one również nawẹ. Nawa kościoła o białych ścianach zmienia sie pod wptywem iluminacii promieni słonecznych które z różnych stron świata przez witraże i kolorowe szkło oświetlaja wnetrze. Przemyślana iluminacia świtta dzienneos wypetnia nawe. Wykreowany i zmienny pod wptywem pó dnia pótmrok w tagodny spośb wydobywa powage miejsca sprzyjając kontemplacji (il. 5). the glass wall of the chancel attracts the attention of the falthrul, he intensily ard colours of the stained glass bilinds them in the bright sunshine. The too bright interior does not create a mood of concentration, only the shadows in the side spaces Another example is the Church of the Holiest Saviour in Rewal where the light was let in through full glazing of a nave wall. The architect applied a plan based on the projection of a circular secto without a separate chancel, where the chancel wall was closed at the meeting point of the circle radii. Two different radii have met forming the arch curvature that is the chancel wall. The resulting part of a circular sector forms the altar zone. The arms ing space between them is the nave the resultIn space between them is the nave of the church. made of stained glass, and in the entrance areaadditional lighting was let in through four narrow vertical windows. The interior space is filled with the source of the fading sunrays, early sunrise an those that appear during the late sunset (il. 4). The Church of Divine Mercy in Szczecin is an example of an orientated building based on an irregular plan, where the light has been let in through the
upper longitudinal skylight, emphasizing the axial upper longitudinal skylight, emphasizing the axia in the diagonal planes of the walls. The temple was designed on the plan of an irregular polygon, completed with a separate chancel, which is underlined by a beam of daylight. The main body of the building consists of obliquely stacked walls of varying heights. The spaces formed between the walls has been filled with stained glass and coloured glass, they light up the nave as well. The nave of the church with white walls changes affected by the
illumination of the rays of sunlight which illuminate the interior from different parts of the world through stained glass and coloured glass. The wellthought-out illumination of daylight fills the nave. The resulting semi-darkness, which changes with every time of the day, gently brings out the solemnity of the place, encouraging contemplation (il. 5). The Church of Blessed Micha Kozal in Swinoujści is another example which uses partial glazing of

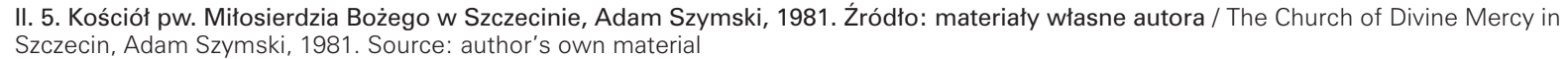

II. 6. Kościót pw. Bt. Michata Kozala w Świnoujśsiu, Rajmund Borowski i Roman Ropel, 1986. Ż́ródto: materiaty własne autora / The Church of
Blessed Michat Kozal in Swinoujśsie, Rajmund Borowski and Roman Ropel, 1986. Source: author's own material
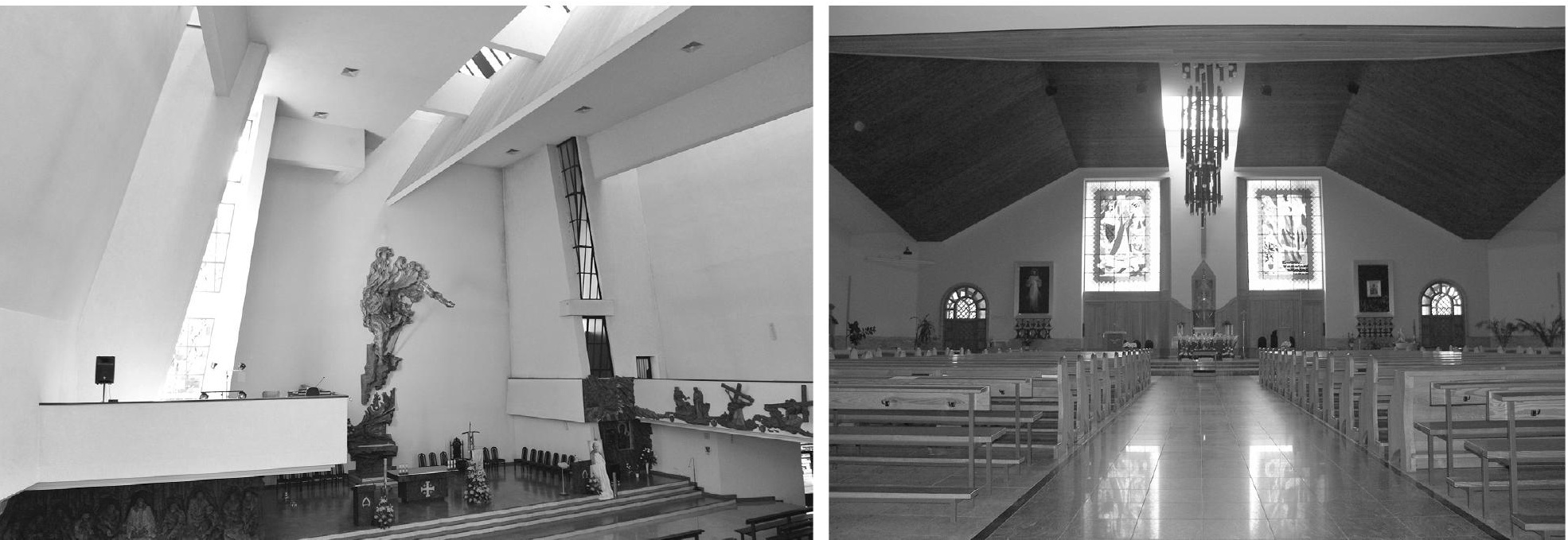

Kolejnym przykładem jest kościół bł. Michała Kozala w Swinoujsciu, w ktorym zas nie ściany prezbiterium w czẹśsi poziomej na wysokości powyżej strefy przewodniczenia. Kościół ten to nieorientowana światynia, oparta na rzucie prostokata ze ścietymi narożnikami, z niewyodrębnionym z rzutu prezbiterium. Ściany boczne nawy opadaja w kierunku ołtarza, w nich umieszczono opadajace rytmicznie rozmieszczone okna, wypełnione witrażami Ściana prezbiterium, we wnetrzu kościoła oddzielona zami. Sciana preźl oświetla pomieszczenie. Natomiast w ścianie prezbiterenie od strony światyni w potowie wysokości umieszczono wewhedrze swzeszlenia wypetione witrazem który góruje nad whętrzne srzeszki w polowie wysokośi unieszzono wewyspa ollarza, okna doswiellaja bezposted hio częsc prezbiwyspa oirara, orka doswela dozposeano czesc prezor dachowy świz sur witrazami Switlo sonecze z okjen bezpostednio i posrednio dociera do wnętrza, tu zostaje pochłonięta przez ciemna kolorystyke whętrza, intensywhy kolor scian, i drewniane wy kończenie sklepienia. W strefie przewodniczenia przez górne doświetlenie dociera jasne czyste światto, które w świątyn podkresla centrum oftarza, te rozbicie natęzenia światła buduje strefowy układ przeznaczenia wnętrza (il. 6).

Częstym sposobem doświetlenia wnętrza jest bezpośrednie oświetlenie słoneczne wprowadzane szczególnie w przestrzeni prezbiterium, jako górne swiatio nakierowane poprzez lunety kierunkowe lub świetliki na prezbiterium lub bezpośrednio na ołtarz. Przykładem wykorzystania tej technik może być m.in. kościół pw. św. Wojciecha w Świnoujściu'. Obiekt orientowany, zaprojektowany jako założenie centralne w połączeniu z układem osiowym. Eliptyczny kształt rzutu przechodzi w dachu w koło, z wyniesionym cylindrycznym zwieńczeniem, wokół którego ściany są ażurowe i wypełnione szkłem. W zwieńczeniu cylindra, w centralnym mieiscu ukryta jest, niewidoczna z poziomu terenu luneta kierunkowa, skupiajaca i wpuszczajaca strumieniem naturalne świeto bezpośrednio na ottarz. Cześciowo ażurowe, przeszivi kolorowym szkłem ściany korpusu doświetlaja wnetrzz. Wnerze kościo wykońzo w biatym kolorze, przeperione jest r kraczaja strefe kruchty majac zapamietany obraz $\mathrm{m}$. Przebry biil o liil okapu dachem, wz ok zatry ju in kolorze światto, kore podświetla centralnie umieszczony $w$ strefie oftarza krzyż. Jest on $w$ prezbiterium wyrażnie zaakcentowany pionowymi filarami, wydzielającymi jego miejsce dodatkowo podkreślone górnym swiattem z lunety kierunkowej. Jest to, jedyne w całej świątyni światło o czystej barwie, co jednoznacznie podkreśla znaczenie miejsce liturgii. Światło optycznie oddziela półmrok, nawy strefy dla wiernych (il. 7). $W$ wielu kościołach $w$ strefie prezbiterium częstym zabiegiem jest stosowanie wąskich pionowych okien jako ukrytego bocznego światła szczelinowego, które jest niewidoczne dl wiernych, a doswietla strefę przewodniczenia. Przykładem może być tu m.in. kościół pw. Opatrzności Bożej w Szczecinie. Wybudowany na planie krzyża łacińskiego, trójnawowy z transeptem, z wydzieloną kruchtą oraz wyodrębnionym the chancel wall in the horizontal part above the presiding area. The church is a non-orientated temple, based on a rectangular plan with bevelled corners, with a non-separated chancel. Side walls the nave fall down towards the altar, they have glass. The wall of the chancel inside the church has been separated by a vertical wall from the sacristy. The sacristy is illuminated by glazing. In the chancel wall, from the side of the temple, at half height there is glazing filled with stained glass which towers over the island of the altar; the windows illuminate directly a part of the chancel and the nave. The allar space is addilon flly illed with stained a skyHere, the sunlight from the windows reaches the interior directly and indirectly, is absorbed by the dark colours of the interior, the intense colour of the walls, and the wooden finish of the vault. The upper additional lighting in the presiding area lets in clear light, which highlights the centre of the altar in the temple, this breakdown of the intensity of he light builds a zonal layout of the interior ( II.6) A common way of lighting the interior is direct sunlight directed through directional telescopes or skylight onto the chancel or directly onto the altar The Church of St. Adalbert in Świnoujście' is an example where this technique is used. The orientated building designed as a central layout in combination with the axial system. The elliptical shape of the projection goes from the roof into a circle, with filled with glass. At the top of the cylinder, in the central part, there is a directional telescope, hidden from the ground, focusing the natural light and letting it in onto the altar. Partly openwork, glazed with coloured glass, the walls of the main body illuminate the interior. The interior of the church decorated in white colour, is filled with colourful light changing with the rhythm of each day. When crossing the porch zone, having in mind the image of the monolith, a mass solidly embedded in the ground bright light which illuminates the cross in centre of the altar zone attracts the visitor's eyes. It is clearly accentuated in the chancel with vertical pillars, marking off its place, additionally underlined by the light from directional telescopes. It is the only light of clear light in the temple, which unequivocally emphasizes the meaning of the liturgy space. Light aptical sop the faithful (il. 7 ).

(i) for the faithful (il. 7).

列 lit light, that is invisible to the faithfudden side minates the presiding area. The Church of Divine Providence in Szczecin may be an example here. Built on the Latin cross plan, three-aisled with a transept, with a separate porch and a separate chancel, closed with a half-circular apse. On the ing the light directly onto the altar. These side windows are not visible to the faithful. The arms of the transept were designed for the chapel, illuminating them with a stained glass wall, closing the side of 
pienie na nim uwagi wiernego, przez snujące się światło jednak nie oślepiające ani rozpraszające uwagę. Dzisiejsze, coraz rzadsze, orientowanie kościołów wpływa na zmianę cyklicznego i podobnego w czasie dla wszystkich świątyń oświetlenia, co również zmienia nastrój wnętrz świątyń. Natomiast wprowadzenie elementu tajemniczości i wzniosłości, może być osiągnięte światłem dziennym, odpowiednio ukierunkowanym przepuszczonym przez szklenie i jego kolory. Pływające światło po fakturach materiałów, użytych do wykończenia wnętrza np. mozaik, cegieł, kamienia, jak również światło odbijające się od użytych kolorów ścian, posadzek, sklepienia wytwarza w odbiorcy wielość różnorodnych odczuć. Tym pożądanym jest numinosum w sztuce i architekturze w odniesieniu do różnych religii wzniosłość, uduchowiona wyższość, obecność elementu magicznego [2]. Wnętrze kościołów podporządkowane jest przede wszystkim liturgii. Jego funkcjonalność związana jest z jej sprawowaniem. Przestrzeń świątyni nie może być pozbawiona „materiału iluminacji” jego umiejętność stosowania kreuje sakralny wyraz wnętrza.

\section{PRZYPISY}

${ }^{1}$ Przykładem mogą być również kaplica Niepokalanego Serca NMP os. Słonecznym w Szczecinie, wspomniany już kościół bł. Michała Kozala, kościół Św. Michała Archanioła w Wielgowie.

2 Kościół św. Jerzego w Goleniowie, pw. Miłosierdzia Bożego w Szczecinie.

${ }^{3}$ Kościół w Gąbinie, w Chomętowie, w Przybiernówku.

${ }^{4}$ Kościół w Międzywodziu, w Szczecinie-Dąbiu, św. Dominika w Szczecinie.

\section{LITERATURA}

[1] Filarska B., Początki architektury chrześcijańskiej, Wydawnictwo Towarzystwa Naukowego KUL, Lublin 1983

[2] Kuryłowicz E., Kościół jako miejsce sztuki czy jako dzieło sztuki, t. VI. Międzynarodowa Konferencja o Architekturze i Sztuce Sakralnej z cyklu „Kościoły naszych czasów" Kościół potrzebuje sztuki, Kielce 2007.

[3] Mroczek A., Kucza-Kuczyński K., Nowe kościoły w Polsce, PAX, Warszawa 1991.

[4] Nadrowski H., Sacrum czasoprzestrzeni, Wydawnictwo Adam Marszałek, Toruń 2012.

[5] Rogińska-Niesłuchowska M., Architektura i światło, Czasopismo Techniczne. Architektura, tom 107, s. 323-327, Wydawnictwo PK, Kraków 2010.

[6] Twarowski M., Metoda projektowania kościoła, Wydaw. Rady Prymasowskiej Budowy Kościołów Warszawy, Warszawa 1985.

\section{STRONY INTERNETOWE}

https://pl.wikipedia.org/wiki/Plik:Church of Light.JPG, dostęp 10.04.2017 https://s-media-cache-ak0.pinimg.com/236x/9b/06/71/9b06710f94fdcff46df96bf 8731a9e18.jpg?noindex=1, dostęp 10.04.2017 and solemnity can be achieved with daylight, appropriately directed and let in through glazing and its colours. The light floating on the texture of the materials used to decorate the interior, e.g. mosaics, bricks, stones, as well as the light reflecting off the used colours of walls, floors, and the vault generates a wide variety of sensations in the recipient. The one that is desired in art and architecture of all religions is numinosum - solemnity, spiritual superiority, presence of the magic element [2]. The interior of churches is subordinated mainly to the liturgy. Its functionality is related to its performance. The space of the temple cannot be deprived of the "material of illumination", its ability to be used creates the sacred nature of the interior.

\section{ENDNOTES}

1 Other examples include the Chapel of the Immaculate Heart of Mary at os. Stoneczne in Szczecin, the already mentioned Church of Blessed Michat Kozal, the Church of St. Michael the Archangel in Wielgowo.

2 The Church of St. George in Goleniów, the Church of Divine Mercy in Szczecin.

${ }^{3}$ Churches in Gabini, in Chometowo, in Przybiernówko.

${ }^{4}$ Churches in Międzywodzie, in Szczecin-Dąbie, the Church of St. Dominic in Szczecin.

\section{BIBLIOGRAPHY}

[1] Filarska B., Początki architektury chrześcijańskiej, Wydawnictwo Towarzystwa Naukowego KUL, Lublin 1983.

[2] Kuryłowicz E., Kościół jako miejsce sztuki czy jako dzieło sztuki, t. VI. Międzynarodowa Konferencja o Architekturze i Sztuce Sakralnej z cyklu „Kościoły naszych czasów” Kościół potrzebuje sztuki, Kielce 2007.

[3] Mroczek A., Kucza-Kuczyński K., Nowe kościoły w Polsce, PAX, Warszawa 1991

[4] Nadrowski H., Sacrum czasoprzestrzeni, Wydawnictwo Adam Marszałek, Toruń 2012.

[5] Rogińska-Niesłuchowska M., Architektura i światło, Czasopismo Techniczne. Architektura, tom 107, s. 323-327, Wydawnictwo PK, Kraków 2010.

[6] Twarowski M., Metoda projektowania kościoła, Wydaw. Rady Prymasowskiej Budowy Kościołów Warszawy, Warszawa 1985.

\section{WEBSITES}

https://pl.wikipedia.org/wiki/Plik:Church_of_Light.JPG, accessed on 10.04.2017

https://s-media-cache-ak0.pinimg.com/236x/9b/06/71/9b06 710f94fdcff46df96bf8731a9e18.jpg?noindex=1, accessed on 10.04.2017 